\title{
Prosopis juliflora Pods Mash for Biofuel Energy Production: Implication for Managing Invasive Species Through Utilization
}

\author{
Mebrahtu Haile ${ }^{a^{*}}$, Hadgu Hishe ${ }^{a}$, Desta Gebremedhin ${ }^{b}$ \\ ${ }^{a}$ Department of Land Resource Management and Environmental Protection, College of Dryland Agriculture and Natural Resources, \\ Mekelle University, Ethiopia
}

${ }^{b}$ Department of Chemistry, College of Natural and Computational Sciences, Mekelle University, Ethiopia,

\begin{abstract}
Fuels obtained from renewable resources have merited a lot of enthusiasm amid the previous decades mostly because of worries about fossil fuel depletion and climate change. The aim of this study was to investigate the potential of Prosopis juliflora pods mash for bio-ethanol production and its hydrolysis solid waste for solid fuel. Parameters such as acid concentration (0.5 - 3 molar), hydrolysis times (5-30 min), fermentation times (6-72h), fermentation temperature $\left(25^{\circ} \mathrm{C}-40^{\circ} \mathrm{C}\right)$ and $\mathrm{pH}(4-8)$ on bio-ethanol production using Saccharomyces cerevisiae yeast were evaluated. Results show that the content of sugar increases as the acid concentration $\left(\mathrm{H}_{2} \mathrm{SO}_{4}\right)$ increase up to 1 molar and decreases beyond 1 molar. A maximum sugar content of $96.13 \% \mathrm{v} / \mathrm{v}$ was obtained at $1 \mathrm{molar}^{\circ} \mathrm{H}_{2} \mathrm{SO}_{4}$ concentration. The optimum conditions for bio-ethanol production were found at 1 molar of $\mathrm{H}_{2} \mathrm{SO}_{4}$ concentration $(4.2 \% \mathrm{v} / \mathrm{v})$, $48 \mathrm{~h}$ fermentation time $(5.1 \% \mathrm{v} / \mathrm{v}), 20 \mathrm{~min}$ hydrolysis time $(5.57 \% \mathrm{v} / \mathrm{v}), 30{ }^{\circ} \mathrm{C}$ fermentation temperature $(5.57 \% \mathrm{v} / \mathrm{v})$ and $\mathrm{pH} 5(6.01 \% \mathrm{v} / \mathrm{v})$. Under these optimum conditions, the maximum yield of bio-ethanol $(6.01 \% \mathrm{v} / \mathrm{v})$ was obtained. Furthermore, the solid waste remaining after bioethanol production was evaluated for solid fuel application $(18.22 \mathrm{MJ} / \mathrm{kg})$. Hence, the results show that Prosopis juliflora pods mash has the potential to produce bio-ethanol. The preliminary analysis of solid waste after hydrolysis suggests the possibility to use it as a solid fuel, implying its potential for alleviating major disposal problems
\end{abstract}

Keywords: Prosopis juliflora pods mash, bio-ethanol, hydrolysis, fermentation, Saccharomyces cerevisiae, solid fuel

Article History: Received March 24th 2018; Received in revised form September 15 ${ }^{\text {th }}$ 2018; Accepted October 1 ${ }^{\text {st }}$ 2018; Available online How to Cite This Article: Haile, M., Hishe, H. and Gebremedhin, D. (2018) Prosopis juliflora Pods Mash for Biofuel Energy Production: Implication for Managing Invasive Species through Utilization. International Journal of Renewable Energy Development, 7(3), $205-212$. https://doi.org/10.14710/ijred.7.3.205-212

\section{Introduction}

One of the greatest challenges for the growing society in this century is to meet the energy demand for transportation, heating, lighting and industrial processes, which have a significant impact on the environment. World population and increased urbanization have directly or indirectly influenced the energy demand (Akpan et al., 2008). In developing countries, especially in rural areas, 2.5 billion people rely on biomass, to meet their energy needs for cooking (Zuzarte, 2007). As in many other countries in the region, fuel supply in Ethiopia is mainly biomass-based $(94.3 \%$ of total energy supply) (Ministry of Mines and Energy, 2011).

Modern fuels are those that are controlled to provide consistent energy, efficient and clean when combusted, such as biofuels or electricity (Zuzarte, 2007). Bio-ethanol is a biofuel which has long been recognized as a fuel suitable for a variety of applications, including transportation and cooking (Prasad et al., 2009). It is one of the safe and environmentally friendly energy since it is made from plants; it does not release any new carbon dioxide (CO2) into the air, unlike fossil fuels which return carbon that was stored beneath the surface for millions of years. It can be made from any sugary or starchy and from cellulosic biomass such as wood, paper pulp or agricultural waste (Pikūnas et al., 2003). Nowadays, research on non- food crops and cellulosic materials has been getting great attention worldwide, because they are cheap, easily available, and profitable as compared to food crops and also reduce inflation of the cost of food crops used for bio-production (Choge et al., 2007).

One of the fastest growing trees which have the potential to substitute food crops for bio-ethanol production could be Prosopis juliflora. It is a tree species native to Northern Mexico and Southern U.S. that survives droughts and thrives in sunny arid regions. The plant fixes its own nitrogen, requires no seeding, fertilization or irrigation, and grows on dry, nutrientpoor soils (Shiferaw et al., 2004). It is a truly promising tree for drylands, because of its multiple and important

\footnotetext{
Corresponding author: mebrahtu.biodiese12013@gmail.com
} 
potential and actual uses, as well as its remarkable resistance to drought, heat, and poor soils (Prasad, 2007). Most often, the tree grows only to become a thorny shrub, but its complex and deep-ranging root system allow it to tap different water tables, both at the surface and deep underground, which makes it a very hardy crop (Pasiecznik et al., 2001). The roots also act as an energy storage mechanism, because once a tree is cut down, new shoots spring up rapidly from the existing roots (Pasiecznik et al., 2001).

The pods produced by Prosopis species are legume pods, high in sugars, starches, and protein. The pods are used as a source of food for human being in history, however, it has turned out to be less important as a human food, somewhat essential as animal feed since the past decades. The pods vary significantly in size between species and even among the population and individual trees of some species (Bravo et al., 1994; Pasiecznik et al., 2001). Pods of all Prosopis species are composed of an exocarp, sometimes fleshy mesocarp, fibrous endocarps and hard seeds. The form and relative amounts of each vary widely between species, with several Prosopis species having a high percentage of mesocarp favored as a source of food and feed (Choge et al., 2007). Prosopis juliflora was introduced to Ethiopia in the 1970s and planted in few areas in the Rift Valley (Abebe, 1994). The species, however, has been spreading in the pastoral areas, making vast rangelands unavailable for grazing, where its removal and management has become already beyond the capacity of the local communities (Admasu 2008; Ryan, 2011). The species has large coppicing potential, which makes its removal very difficult and expensive. The invasiveness of the species has been aggravated by animals which feed on it, such as camel, goats, and cattle in Afar (Hailu et al., 2004).

Prosopis juliflora is found dominantly on the arid part of Ethiopia like Afar, and in some parts of Oromia, Dire Dawa, Tigray, Somali, Southern Nations, Nationalities and Peoples (SNNP) and Amahara regions (Steele, 2009). It is a fast-growing tree species and it could be a good source of bio-ethanol production to reduce dependency on the rapidly increasing price of petroleum crude and products, as well as to manage its invasion in the environment. The conversion of the various parts of the species into alternative uses could also create new jobs that benefit farmers and pastoral communities, for instance by improving their access to livestock feeds and income from bio-ethanol production. In addition, the conversion of the pods into bio-ethanol and the seeds into biochar have the advantage of controlling its invasion into a new area. The main objective of this research was to evaluate the potential of P. juliflora pods for bioethanol production and its solid waste by-product as solid fuel.

\section{Materials and Methods}

\subsection{Sample collection}

The pods of $P$. juliflora were collected at Amibara, one of the severely invaded woredas in Afar region, Ethiopia. Healthy $P$. juliflora trees were selected and dry pods were collected. The collected composite pods were taken in plastic bags and dispatched to Mekelle University laboratory for further work. The experiment was conducted in a laboratory at Mekelle University, Adigrat medical laboratory and Geological survey of Ethiopia central laboratory, following the methods mentioned in Onuki (2005).

\subsection{Dry and Milling}

The $P$. juliflora pods were sun-dried and broken down to a fine powder using a hammer mill process. The grinding increased surface area of the pods and enhance the contact between starch and acid or water. The seed of $P$. juliflora was hard to mill by hammer milling and only the pod was used for this experiment and we recommend the seeds to be used as a biochar feedstock. Compared to the amount of the pod, the amount of seed obtained from a large collection of the pod was very small in amount/content and not economical to use alone for bioethanol production.

\subsection{Determination of Moisture Content}

The $P$. juliflora pod was dried using an oven at $105{ }^{\circ} \mathrm{C}$ followed by cooling in a desiccator over silica gel $(0 \%$ relative humidity) and weighing until a constant weight. The moisture content was determined as in equation 1 :

Moisture content $(\%)=\frac{w_{1-} w_{2}}{w_{1}} \times 100$

Where $w_{1}$ and $w_{2}$ are the weights of the sample before (g) and after drying $(\mathrm{g})$, respectively

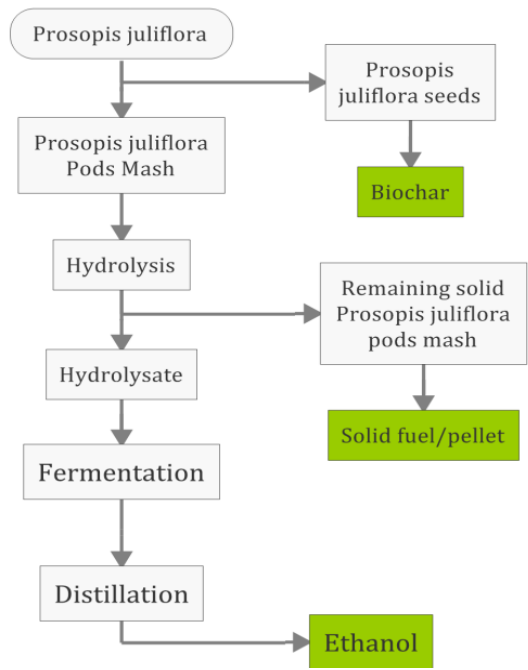

Fig. 1. The path for the production of bio-ethanol and its valueadded from $P$. juliflora pods mash

\subsection{Hydrolysis}

The $P$. juliflora pod powder $(25 \mathrm{~g})$ was hydrolyzed (pretreated) employing different concentrations of sulfuric acid (each of 0.5, 1, 1.5, 2, 2.5 and 3 molars) and with $250 \mathrm{ml}$ of distilled water in $500 \mathrm{ml}$ Erlenmeyer flask and separately heated at $90{ }^{\circ} \mathrm{C}$ for 15 minutes. After hydrolysis, the liquid fraction was cooled, filtered with filter suction and determined for glucose concentration. The distilled water and acid hydrolysates were adjusted to $\mathrm{pH} 5-6$ by adding concentrated sulfuric acid and $2 \mathrm{~N}$ 
sodium hydroxide, and the solutions were filtered and prepared for fermentation (Dawson and Boopaty, 2008).

\subsection{Fermentation}

\subsubsection{Source of Microorganism for fermentation}

The microorganisms from S. cerevisiae, purchased from the local market was used in the experiments. The yeast was first dissolved in warm water and left for $10 \mathrm{~min}$ before being used. Then the prepared solutions were taken into the flask containing hydrolysate sample. Batch fermentations of hydrolysis were carried out in $500 \mathrm{ml}$ Erlenmeyer flask incubated with $5 \mathrm{~g} / \mathrm{l} S$. cerevisiae at $30{ }^{\circ} \mathrm{C}$ as described in the literature (Thuesombat et al., 2007). The hydrolysate treatment was carried out using distilled water (zero) and different molars of sulfuric acid (0.5, 1, 1.5, 2, 2.5 and 3 mollars).

\subsubsection{Ethanol Fermentation}

After scarification, the substrates were allowed to ferment in yeast ( $S$. cerevisiae). The set up was left under anaerobic condition for $24 \mathrm{~h}$ with the different $\mathrm{H}_{2} \mathrm{SO}_{4}$ concentrations $(0,0.5,1,1.5,2,2.5$ and $3 \mathrm{M})$ to select the best treatment type for bio-ethanol production. The substrate with the best bio-ethanol yield was subjected for optimization with different periods of fermentation times $(6,12,24,36,48$ and $72 \mathrm{~h})$, hydrolysis times $(5,10$, $15,20,25,30 \mathrm{~min})$, and fermentation temperatures (25 ${ }^{\circ} \mathrm{C}, 30^{\circ} \mathrm{C}, 35^{\circ} \mathrm{C}$ and $40{ }^{\circ} \mathrm{C}$ ), $\mathrm{pH}(4,5,6,7$ and 8)(Ayele et al., 2012) keeping the optimized parametrs constant.

\subsubsection{Biothanol Recovery}

The bio-ethanol was separated from the fermented sample by fractional distillation method. The fermented solution was heated to force the lowest boiling material into the vapor phase. The vapors were passed over the fractional column and the bulb of a thermometer at which point vapor was determined. The vapor was condensed to a liquid in the horizontal condenser that was cooled by a flow of cold water. The distillate was collected in a receiver. The weight of the distillate was measured.

\subsubsection{Yield calculations}

First, the gram of bio-ethanol was calculated based on the collected amount and concentration of bio-ethanol and expressed on a weight basis. The bio-ethanol yield was then calculated based on the gram of bio-ethanol and the sample taken.

$$
\mathrm{Ge}=\frac{(\mathrm{Ce} \times \mathrm{Ac})}{100}
$$

Where Ge, Ce and Ac are the gram of bio-ethanol (g), concentration of bio-ethanol and the amount collected (g)

Yield of bioethanol $(\%)=\frac{\text { Gram of bioethanol }(\mathrm{g})}{\text { Sample }(\mathrm{g})}$

\subsection{Analytical Methods}

\subsubsection{Determination of Sugar Contents}

The sugar contents of the samples during saccharification of the substrates were estimated as per the method described in Ayele et al (2012). Fehling method was used to determine the reducing sugar concentration. $50 \mathrm{ml}$ of the hydrolyzed sample solution was taken and dissolved in $10 \mathrm{ml}$ of distilled water and mixed with $2 \mathrm{ml}$ of cons. $\mathrm{HCl}$ acid and was heated for a period of $10 \mathrm{~min}$. The obtained sample was neutralized by adding $\mathrm{NaOH}$ and prepared in $300 \mathrm{ml}$ conical flask and taken into the burette. The $10 \mathrm{ml}$ of Fehling solution was taken and mixed with $90 \mathrm{ml}$ of distilled water in 250 $\mathrm{ml}$ Erlenmeyer flask and Methyl blue indicator was added. The conical flask solution was titrated with burette solution in boiling conditions until disappearance of blue color and the volume at which brick red color observed were recorded. For each sample the sugar content was calculated by using the formula given below:

Sugar content $(\%)=\frac{300 \mathrm{~mL} x f}{v} \times 100 \%$

Where the f-Fehling factor (0.051); v-volume used in the titration (titrate value) $(\mathrm{ml})$

\subsubsection{Determination of Ethanol Concentration}

The Fourier Transform Infrared (FTIR) (65, PerkinElmer, UK) response was calibrated using different concentrations of pure ethanol. The measurement was carried out in reflectance mode where ZnSe (Zinc selenide) window was used as a sample holder. After the absorbance of pure ethanol was recorded the calibration curve was constructed first in weight-to-weight and then converted to volume-tovolume concentration units. The concentrations of ethanol were determined using the absorbance obtained for each sample from the calibration curve. The calibration curve was constructed using the absorbance values obtained for the different ethanol concentrated solutions (Figure 2). The data points were fitted with a second order polynomial fit of the form.

$y=a x^{2}+b x+c$

Where $y$ and $x$ represent the absorbance and the concentration respectively, $a$ and $b$ are fit values that represent second and first order slope, respectively, and $c$ is the absorbance bias where the concentration is 'zero'. From the fit $c=0.00159, a=-0.00064 \mathrm{~mol}^{-2} \mathrm{~L}^{2}$ and $b=0.05363 \mathrm{~mol}^{-1} \mathrm{~L}$ were at $\mathrm{p}$-value $\left.<0.0001\right)$.

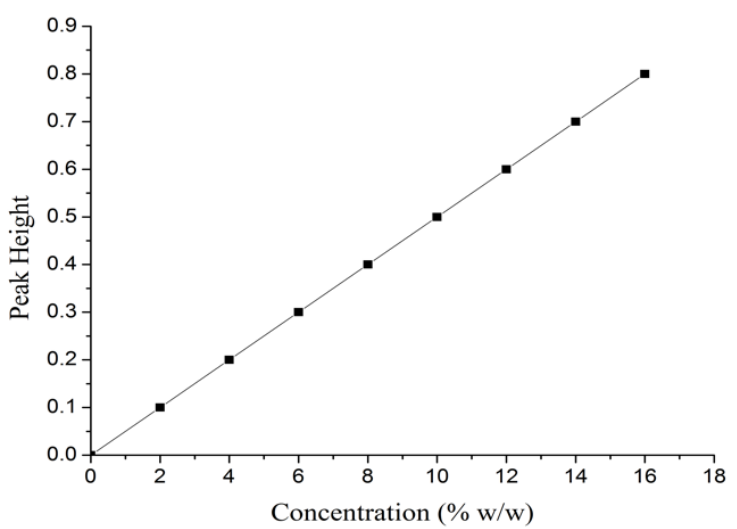

Fig. 2 Calibration curve for ethanol standard solution 
The value of $b$ is more than one order of magnitude greater than $c$ indicating the absorbance residual bias is very small leading to the high sensitivity of the method with a standard deviation of $\mathrm{SD}=0.00334$. The regression value of $R^{2}=0.99972$ further confirms the reliability of the fit. The calibration curve revealed excellent accuracy and sensitivity, and therefore, was used for determining the concentrations of the samples from the absorbance reading.

\subsection{Determination of P. juliflora pod Calorific Value after Hydrolysis}

The solid waste after hydrolysis of $P$. juliflora was characterized for solid fuel. The sample waste after hydrolysis was taken for calorific value determination with bomb adiabatic calorimetric instrument and calculated by using the formula given below:

$$
\mathrm{Hg}=\frac{\mathrm{TW}-\mathrm{e}_{1}-\mathrm{e}_{2}-\mathrm{e}_{3}}{\mathrm{~m}}
$$

Where $\mathrm{Hg}=$ Gross Heat Combustion

$\mathrm{T}=$ Temperature difference $\left({ }^{\mathrm{O}} \mathrm{C}\right)$

$\mathrm{W}=$ energy equivalent of calorimetric in $\mathrm{Cal} /{ }^{\mathrm{O}} \mathrm{C}(2420$ $\left.\mathrm{Cal} /{ }^{\circ} \mathrm{C}\right)$

$\mathrm{e}_{1}=$ correction in calories for heat of formation of $\mathrm{HNO}_{3}$ $(24.2 \mathrm{Cal}) *$ titrate volume $(\mathrm{ml})$

$\mathrm{e}_{2}=$ correction in calories for heat formation of $\mathrm{H}_{2} \mathrm{SO}_{4}$ $(13.7 \mathrm{Cal})$ * content of sulfur (negligible)

$\mathrm{e}_{3}=$ correction in calories for heat formation of fuse wire $(2.3)$ * length of fuse wire combusted $(\mathrm{cm})$ $\mathrm{m}=$ weight of sample

\section{Results and discussion}

\subsection{Effect of Acid Concentration on Sugar Content}

The values of sugar contents obtained from $P$. juliflora in this study were shown in the figure below (figure 3). This $P$. juliflora reducing sugars were saccharified with different $\mathrm{H}_{2} \mathrm{SO}_{4}$ concentrations and distilled water at $90^{\circ} \mathrm{C}$ and 15 min hydrolysis time after the determination of moisture content (15.65\%). Figure 3 shows that $P$. Juliflora pods mash has $57.34 \%$ sugar content after it was saccharified with distilled water. The sugar content increased with an increase in acid concentration up to $1 \mathrm{M}$, and at this concentration, the highest value of $96.13 \%$ sugar content was obtained. Further increase in acid concentration led to a decrease in sugar content (figure 3). The increase of sugar contents in acid treated samples with increasing acid concentration may be due to a complete and fast conversion of cellulose to glucose and hemicelluloses to $\mathrm{C}_{5}$-sugars (Nutawan et al., 2010) and as the solution was more concentrated, the monomeric sugars (xylose, glucose) may further be oxidized to undesirable byproducts such as furfural, hydroxyl methyl furfural (HMF), etc. by sulfuric acid on glucose (Joshi et al., 2011; Nutawan et al., 2010).

\subsection{Parameters affecting bio-ethanol Production \\ 3.2.1. Acid Concentration}

The optimum acid concentration determination was carried out with distilled water and different concentrations of $\mathrm{H}_{2} \mathrm{SO}_{4}$, while keeping all the other parameters constant, i.e. $90^{\circ} \mathrm{C}$ hydrolysis temperatures, 15 min hydrolysis time, $\mathrm{pH} 5,24 \mathrm{~h}$ fermentation time and $30{ }^{\circ} \mathrm{C}$ fermentation temperature were applied for all concentration samples.

Figure 4 shows that the bio-ethanol yields obtained in distilled water and $0.5 \mathrm{M} \mathrm{H}_{2} \mathrm{SO}_{4}$ concentrations were $1.53 \%$ and $2.65 \% v / v$, respectively, and the maximum bioethanol yield of $4.2 \% \mathrm{v} / v$ was obtained in $1 \mathrm{M}$ of $\mathrm{H}_{2} \mathrm{SO}_{4}$ concentrations. Further increase in acid concentration (1.5, 2, 2.5 and $3 \mathrm{M} \mathrm{H}_{2} \mathrm{SO}_{4}$ ) resulted in a decrease in bioethanol yield of 3.3, 2.7, 2.1 and $1.7 \% v / v$, respectively. Decreasing bio-ethanol yield at a higher acid concentration may be due to degradation of monomeric sugars to undesirable by-products or may be derived from dehydrating or oxidizing effect of sulfuric acid on glucose instead of forming bio-ethanol (Nutawan et al., 2010).

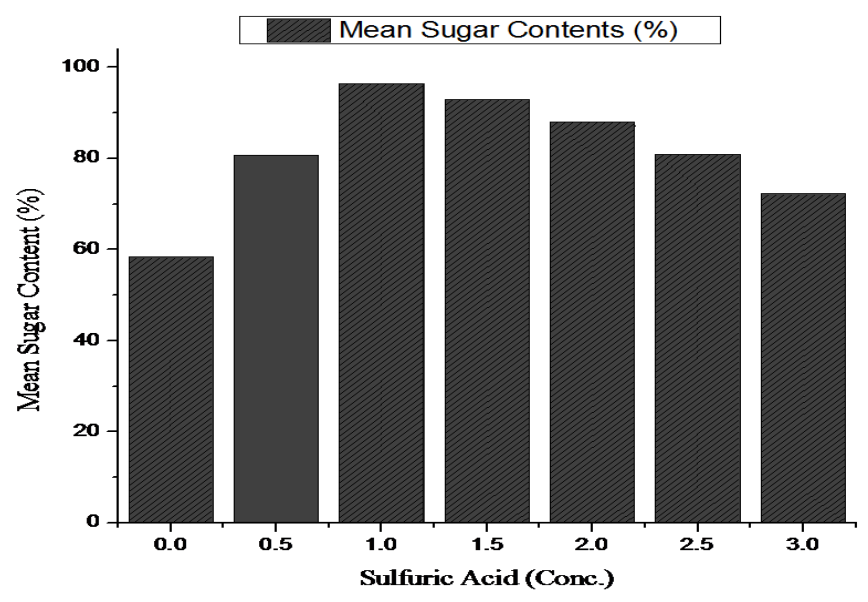

Fig. 3 The effect of acid concentrations on sugar content 


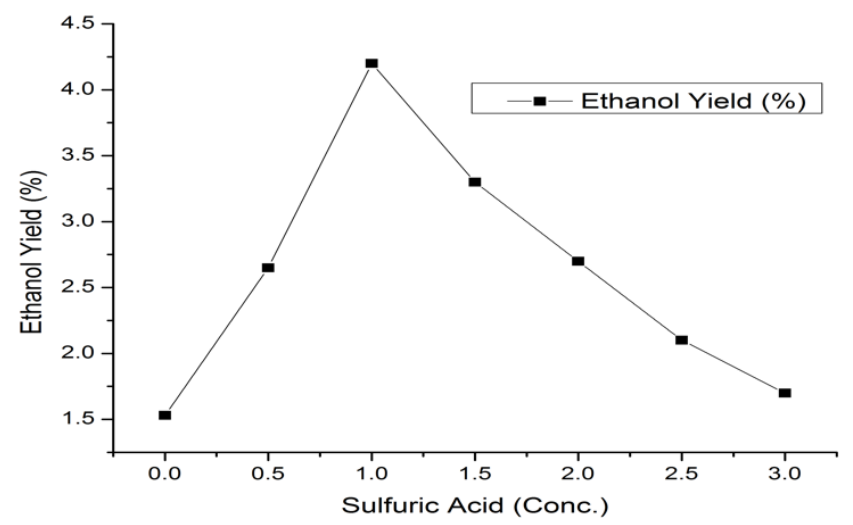

Fig. 4 The effect of acid concentration on bio-ethanol production

\subsubsection{Fermentation Time}

As shown in figure 5, the optimization of fermentation time for bio-ethanol production were adjusted ranged from 6-72 $\mathrm{h}$ keeping the other parameters constant $\left(1 \mathrm{M} \mathrm{H}_{2} \mathrm{SO}_{4}\right.$ - optimum acid concentration obtained from the previous experiment, $90{ }^{\circ} \mathrm{C}$ hydrolysis temperature, $15 \mathrm{~min}$ hydrolysis time, $\mathrm{pH} \quad 5$ and $30{ }^{\circ} \mathrm{C}$ fermentation temperatures).

Figure 5 shows that bio-ethanol yield obtained at 6,12 , 24 and $36 \mathrm{~h}$ fermentation times were $3.12 \%, 3.5 \%, 3.67 \%$ and $4.43 \% v / v$, respectively. At $72 \mathrm{~h}$ fermentation time, the least bio-ethanol concentration $(1.92 \% v / v)$ was found, whereas, the maximum bio-ethanol yield $(5.1 \% v / v)$ was obtained at $48 \mathrm{~h}$ fermentation time. The result revealed that the amount of bio-ethanol increased with increase in fermentation time up to a maximum of $48 \mathrm{~h}$ fermentation times, and then after it starts to decrease. This may be due to the consumption of sugar by the microorganisms or the hydrolysate does contain significant levels of metabolic inhibitors (e.g., furfural and HMF) that can interfere with fermentation (Weil et al., 2002).

\subsubsection{Hydrolysis Time}

Hydrolysis time was taken as another parameter for bioethanol production optimization. In the optimization of hydrolysis time, the solutions were kept for $5,10,15,20$, 25 and $30 \mathrm{~min}, \mathrm{pH} 5$ and $30^{\circ} \mathrm{C}$ fermentation temperature, heated at hydrolysis temperature of $90^{\circ} \mathrm{C}$, while keeping the other optimized parameters constant.

The result showed that bio-ethanol yield in $5,10,15$, 20,25 and 30 minutes of hydrolysis times, which were given $3.78 \%, 4.72 \%, 5.16 \%, 5.57 \%, 4.4 \%$ and $2.83 \% v / v$, respectively. The maximum bio-ethanol yield $(5.57 \% \mathrm{v} / \mathrm{v})$ was obtained at 20 min hydrolysis time as shown in Figure 6 . The result showed that the bio-ethanol yield increases with increasing hydrolysis time and reaches optimum at $20 \mathrm{~min}$ hydrolysis time. The result obtained is in agreement with what was reported by Ayele et al. (2012).

The bio-ethanol yield was decreased beyond $20 \mathrm{~min}$ as hydrolysis time increases, may be due to the fact that longer residence time makes the sugars further oxidize to form inhibitors (furfural) (Nutawan et al., 2010).

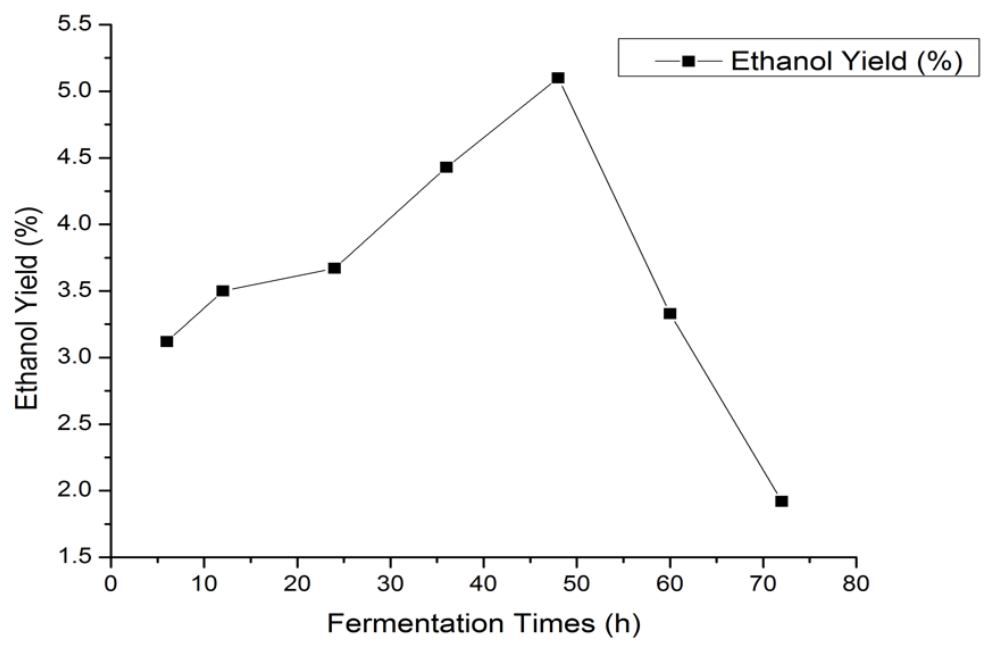

Fig. 5 The effect of fermentation time on bio-ethanol production 


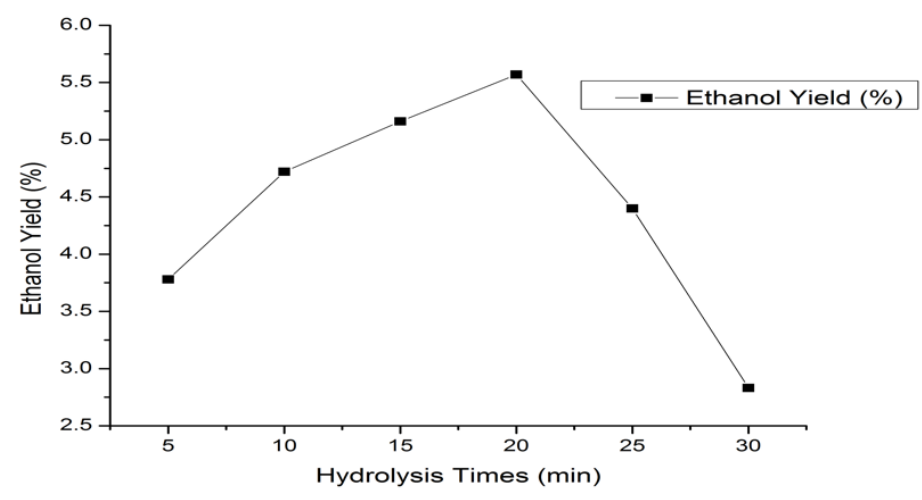

Fig. 6 The effect of hydrolysis time on bio-ethanol production

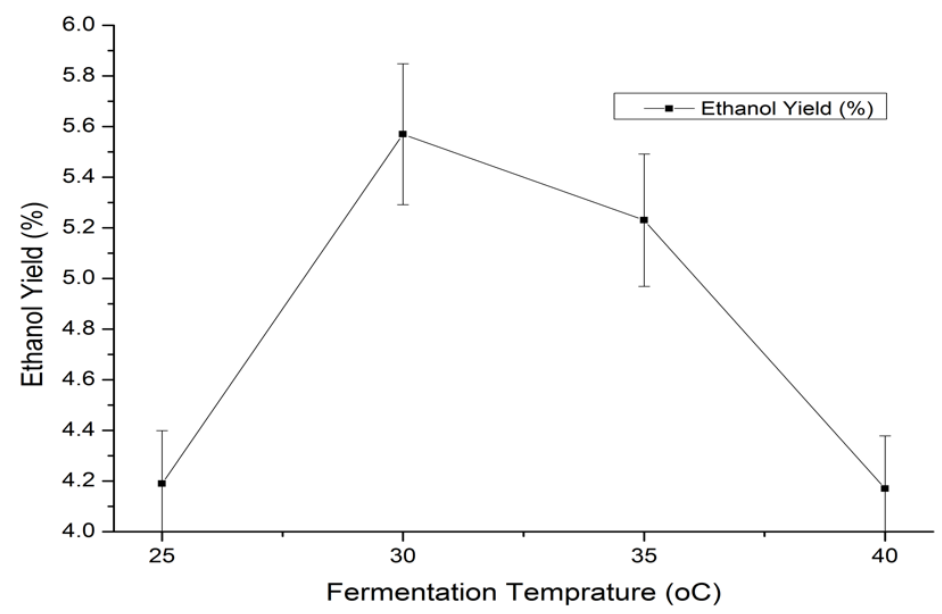

Fig. 7 The effect of fermentation temperature on bio-ethanol production

\subsubsection{Fermentation Temperature}

As in Figure 7, the optimization of fermentation temperature was carried out in $25,30,35$ and $40{ }^{\circ} \mathrm{C}$, whereas all the optimized, as well as hydrolysis temperature $\left(90^{\circ} \mathrm{C}\right)$ and $\mathrm{pH} 5$ was kept constant.

Figure 7 shows that bio-ethanol yields obtained with fermentation temperatures of $25,30,35$ and $40^{\circ} \mathrm{C}$ were $4.19 \%, 5.57 \%$, and $5.23 \%$ and $4.17 \% v / v$ respectively. According to these results, bio-ethanol yield increases from $25{ }^{\circ} \mathrm{C}-30{ }^{\circ} \mathrm{C}$ fermentation temprature. However, increasing the temperature beyond $30^{\circ} \mathrm{C}$ decreased the bio-ethanol yield of $P$. juliflora pods mash. As the result shows, the bio-ethanol yield was found maximum at $30^{\circ} \mathrm{C}$ $(5.57 \% \mathrm{v} / \mathrm{v})$. Fermentation temperature is one of the major constraints that determine the bio-ethanol production. Too high temperature kills yeast, and low temperature slows down yeast activity (Hoi, 2003).

\subsection{5. $p H$ Value}

Besides the other parameters, the $\mathrm{pH}$ value of the bioethanol production was optimized keeping all other parameters constant. As figure 8 shows, the $\mathrm{pH}$ from $4-8$ was taken and the result revealed that $4.5 \%, 6.01 \%$, $5.31 \%, 2.7 \%$ and $2.2 \% \mathrm{v} / \mathrm{v}$ respectively. The maximum bioethanol yield was found at $\mathrm{pH} 5$.

It is worthwhile to mention that the concentration of bio-ethanol obtained $(6.01 \% \mathrm{v} / \mathrm{v})$ by the hydrolysis of the
Prosopis julflora pods mash is satisfactory compared to the maximum amount of bio-ethanol obtained from fermentation of Poultry manure $(5 \mathrm{~g} / \mathrm{L}$ ) (Woldesenbet et al., 2013), spent coffee ground after biodiesel production $(6.5 \mathrm{~g} / \mathrm{L})$ (Haile et al., 2013), wet coffee waste $(6.12 \mathrm{~g} / \mathrm{L})$ (Woldesenbet et al., 2016).

However, the result of this study is very low as compared with bio-ethanol potential of Sugarcane bagasses (10.2 g/L) (Raghavendra and Havannavar, 2007) and Banana peels $(9.8 \mathrm{~g} / \mathrm{L})$ (Manikandan and Saravanan, 2008).

\subsection{P. juliflora as a solid fuel potential after Hydrolysis}

The calorific value of $P$. juliflora after bio-ethanol production was recorded as $18.22 \mathrm{MJ} / \mathrm{kg}$. In particular, it has high calorific value compared to the conventional biomass, as in (Hoi, 2003), like bagasse (7.7-8 MJ/Kg), rice husks (14 MJ/Kg), coffee husk (16 MJ/Kg) and wood (8.417) but less than the calorific value of spent coffee ground $(20.8 \mathrm{MJ} / \mathrm{kg})$ after hydrolysis and spent coffee ground and glycerin ratio (glycerin content from 20-40\%) (19.3-21.6 $\mathrm{MJ} / \mathrm{Kg}$ ) (Haile et al., 2013; Haile, 2014). This result showed the possibility of utilizing $P$. juliflora after hydrolysis as a raw material for solid fuel production. This has a significant contribution to energy supply, while also solving the disposal of wastes after hydrolysis. 


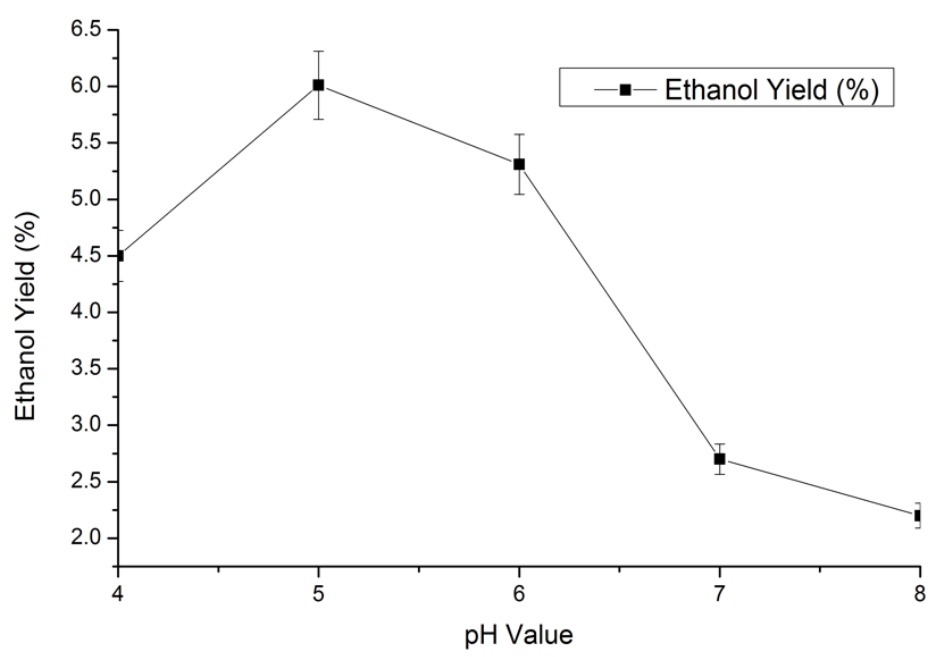

Fig. 8 The effect of $\mathrm{pH}$ value on bio-ethanol production

\section{Conclusions}

The aim of this work was to evaluate $P$. juliflora pods as a potential alternative feedstock for bio-ethanol production and its by-product as a solid fuel. The findings of the present result concluded that $P$. juliflora has the potential for bio-ethanol production, as well as solid fuel after hydrolysis. The maximum amount of bio-ethanol yield $(6.01 \% v / v)$ was obtained after $1 \mathrm{M} \mathrm{H}_{2} \mathrm{SO}_{4}, 48 \mathrm{~h}$ of fermentation time, $20 \mathrm{~min}$ of hydrolysis time, $\mathrm{pH}(5)$ and $30{ }^{\circ} \mathrm{C}$ of fermentation temperature. However, the produced quantity of bio-ethanol is not proportioned to the amount of sugar content in the samples due to $S$. Cerevisiae yeast can ferment only C6 sugars. Additionally, the calorific value of $P$. juliflora after hydrolysis $(18.22$ $\mathrm{MJ} / \mathrm{kg}$ ) implies the possibility of combining hydrolysis $P$. juliflora for bio-ethanol production with energy production. This contributes to minimizing the use of fuelwood, charcoal, dung cakes, agricultural residues and fossil fuel as the energy source, which has various reported environmental consequences. Additionally, its use contributes to minimizing rising bio-ethanol production from first generation feedstocks such as food crop which has its impact on food security. Based on these premises, we argue that $P$. juliflora is a promising alternative feedstock for bio-ethanol production and the findings in this study imply alternative means to reduce the global warming arising from combustion of fossil fuel and arresting the invasiveness of the species in various localities in Ethiopia.

\section{Acknowledgments}

We would like to acknowledge Mekelle University for the recurrent financial support that allowed us to undertake the research work.

\section{References}

Abebe, T. (1994) Growth-performance of some multi-purpose trees and shrubs in the semiarid areas of southern Ethiopia. Agroforestry Systems, 26, 237-248.
Admasu, D. (2008) Invasive plants and food security: The case of Prosopis juliflora in the Afar region of Ethiopia. FARM-Africa, IUCN, 1-13.

Akpan, U.G., Alhakim, A. A. \& Ijah, U. J.J. (2008) Production of ethanol Fuel from Organic and Food Wastes. Leonardo Electronic Journal of Practices and Technologies ISSN 15831078, 1-11.

Ayele, K., Mesfin, R. \& Araya, A. (2012) Potential of Bioethanol Production and Optimization Test from Agricultural Waste; the Case of Wet Coffee Processing Waste (Pulp). International Journal of renewable energy research, 2 (3).

Bravo, L., Grados, N. \& Saura-calixto, F. (1994) Composition and potential uses of mesquite pods (Prosopis pallida L) comparison with carob pods (Ceratonia siliqua L). Journal of the Science of Food and Agriculture 65, 303-306.

Choge, S.K., Pasiecznik, N.M., Harvey, M., Wright, J., Awan, S.Z., \& Harris, P.J. (2007) Prosopis pods as human food, with special reference to Kenya. Nairobi, Kenya Forest Research Institute, 33 (3), 419-424.

Dawson, L. \& Boopaty, R. (2008) Cellulosic ethanol production from sugarcane bagasse without enzymatic saccharification. Bioresources 3, 452-460.

Hailu, S., Demel, T., Sileshi, N. \& Fassil, A. (2004) Some biological characteristics that foster the invasion of $P$. juliflora (Sw.) DC.At Middle Awash Rift Valley, Northeastern Ethiopia. Journal of Arid Environment 58, 34-153.

Hoi, W. (2003) Potential of biomass utilization for energy in Asia Pacific experience of the Philippine situation, Forest Research Institute. Kepong, Kuala Lumpur Malaysia.

Joshi, B., Raj Bhatt, M., Sharma, D., Joshi, J., Malla, R. \& Sreerama, L. (2011) Lignocellulosic ethanol production: Current practices and recent developments. Biotechnology and Molecular Biology Review, 6(8), 172-182.

Haile, M. (2014) Integrated volarization of spent coffee grounds to biofuels. Biofuel Research Journal 2, 65-69.

Haile, M., Araya, A., \& Nigist, A. (2013) Investigation of Waste Coffee Ground as a Potential Raw Material for Biodiesel Production. International journal of renewable energy research, 3 (4).

Manikandan K, Saravanan S. (2008) Kinetics studies on bioethanol production from banana peel waste using mutant strain of Saccharomyces cervisiae. Indian J Biotechnol.; 7:8388.

Ministry of Mines and Energy (2011) Energy Policy of Ethiopia, Japan International Cooperation Agency (JICA) Tokyo international center.

Nutawan, Y., Phattayawadee, P., Pattranit, T. \& Mohammad, N. (2010) Bioethanol Production from Rice Straw. Energy Research J. 1, 26-31. 
Onuki, S. (2005) Bioethanol, Industrial production process, and recent studies; USA organic and food wastes. Journal of Practices and Technologies, 13, 1-11.

Pasiecznik, N.M., Felker, P., Harris, P.J., Harsh, L.W., Cruz, G., Tewari, J.C., Cadoret, K. \& Maldonado, L.J. (2001) The Prosopis juliflora - Prosopis pallida Complex: a monograph. HDRA, Coventry, UK.pp 162.

Pikūnas, A., Pukalskas, S. \& Grabys, J. (2003) Influence of composition of gasoline-ethanol blends on parameters of internal combustion engines. Journal of kones internal combustion Engines, 10, 3-4.

Prasad, M.N.V. (2007). Phytoremediation in India. In: Willey, N. (ed.) Methods in Biotechnology: Phytoremediation: Methods and reviews. Humana Press Inc., Totowa, USA, 23, 433-452

Prasad, M.P., Rekha, S., Tamilarasan, M. \& Subha, K.S. (2009). Production Of Bioethanol Using Various Agricultural Raw Materials By Two Step Enzymatic Process. Advanced Biotech, $41-43$.

Raghavendra B, Havannavar Geeta SG. (2007) Pre-treatment of agroresidues for release of maximum reducing sugar. Karnataka J Agric Sci. 20:771-772.

Ryan, F. (2011) US Forest Service Technical Assistance, Trip to Ethiopia: Invasive species management. Report Submitted to USAID.

Shiferaw, H., Teketay, D., Nemomissa, S. and Assefa, F. (2004). Some biological characteristics that foster the invasion of
Prosopis juliflora (Sw.) DC. at Middle Awash Rift Valley Area, northeastern Ethiopia. Journal of Arid Environments, 58: 134-153

Steele, P., Breithaupt, J., \& Labrada, R. (2009) Increased food security: control and management of Prosopis. Proceedings of an Expert Consultation, 4, Awash (Ethiopia), FAO.

Thuesombat, P., Thanonkeo, P., Laopaiboon, L., Laopaiboon, P., Yunchalard, S., Kaewkannetra, L. \& Thanonkeo, S. (2007) The batch ethanol fermentation of Jerusalem artichoke using saccharomyces cerevisiae. Journal of sciences and Technology 7:93-96.

Weil, J., Dien, B., Bothast, R., Hendrickson, R., Mosier, N. \& Ladisch, M. (2002) Removal of fermentation inhibitors formed during pretreatment of biomass by polymeric adsorbents. Ind. Eng. Chem. Res. 41, 6132-6138.

Woldesenbet AG, Shiferaw G, Chandravanshi BS. (2013) Bioethanol production from poultry manure at Bonga Poultry Farm in Ethiopia. Afr J Environ Sci Technol. 7:435-440.

Woldesenbet AG, Woldeyes B, Chandravanshi BS. (2016) Bio-bioethanol production from wet coffee processing waste in Ethiopia. Springerplus. 5(1): 1903.

Zuzarte, F. (2007) Ethanol for Cooking - Feasibility of Small-scale Ethanol Supply and its Demand as a Cooking Fuel: Tanzania Case Study. KTH School of Energy and Environmental Technology, Heat and Power Technology, Stockholm, Sweden. 